\title{
Photocatalysis for Heavy Metal Treatment: A Review
}

\author{
Xinyu Gao and Xiangchao Meng *(D) \\ Department of Chemical Engineering, Ocean University of China, Qingdao 266100, China; \\ xinyu_gao@hotmail.com \\ * Correspondence: mengxiangchao@ouc.edu.cn; Tel.: +86-0532-6678-2718
}

Citation: Gao, X.; Meng, X. Photocatalysis for Heavy Metal Treatment: A Review. Processes 2021, 9, 1729. https://doi.org/10.3390/ pr9101729

Academic Editor: Chiing-Chang Chen

Received: 19 August 2021

Accepted: 20 September 2021

Published: 27 September 2021

Publisher's Note: MDPI stays neutral with regard to jurisdictional claims in published maps and institutional affiliations.

Copyright: (c) 2021 by the authors. Licensee MDPI, Basel, Switzerland. This article is an open access article distributed under the terms and conditions of the Creative Commons Attribution (CC BY) license (https:// creativecommons.org/licenses/by/ $4.0 /)$.

\begin{abstract}
Environmental and human health are threatened by anthropogenic heavy metal discharge into watersheds. Traditional processes have many limitations, such as low efficiency, high cost, and by-products. Photocatalysis, an emerging advanced catalytic oxidation technology, uses light energy as the only source of energy. It is a clean new technology that can be widely used in the treatment of organic pollutants in water. Given the excellent adaptability of photocatalysis in environmental remediation, it can be used for the treatment of heavy metals. In this comprehensive review, the existing reported works in relevant areas are summarized and discussed. Moreover, recommendations for future work are provided.
\end{abstract}

Keywords: photocatalysis; heavy metal; treatment; removal

\section{Introduction}

Heavy metals are defined as metals with relatively high densities (metals where the density is usually greater than $5 \mathrm{~g} / \mathrm{cm}^{3}$ ), high atomic weights, and high atomic numbers. Heavy metals pose a great threat to the ecosystem, which, in turn, affects human health. The presence of heavy metals, such as mercury, lead, copper, nickel, cadmium, or arsenic, can accumulate in the human body, causing organ failure or cancer and can severely endanger human health. In addition to direct health effects, the heavy metal pollution in in water bodies and the atmosphere can also lead to the poisoning of animals and plants, resulting in reduced crop yields, a shortage of food and water sources, ecological balance, and biodiversity damage. This would further induce large economic losses and disturb geographical and ecological balance because they are difficult to transform or degrade into harmless substances [1,2]. The common uses and health effects of several heavy metal elements are summarized in Table 1 . Therefore, the proper disposal of heavy metal pollutants is imperative.

Photocatalysis is a popular technology among these new advanced oxidation technologies and exhibits promise in various areas [3-7]. Figure 1 illustrates a schematic diagram of the basic principle of the photocatalytic process. Generally, photocatalysts have semiconductor structures. When the semiconductor material is irradiated by light, electrons $\left(\mathrm{e}^{-}\right)$located in the valence band may jump to $\mathrm{CB}$ and may leave a positively charged hole $\left(\mathrm{h}^{+}\right)$on the VB if the energy of a photon in the incident light is greater than or equal to the bandgap energy between the semiconductor valence band (VB) and the conduction band (CB). This pair of $\mathrm{h}^{+}$and $\mathrm{e}^{-}$can, respectively migrate to the surface of the semiconductor to undergo a series of oxidation and reduction reactions, which are embodied in the conversion of different valence states in the treatment of heavy metals [8-10]. In the photocatalysis process, the most essential limiting factors are the high energy requirements of the incident light caused by the wide bandgap and the easy recombination of photogenerated carriers $\left(\mathrm{e}^{-}\right.$and $\left.\mathrm{h}^{+}\right) . \mathrm{TiO}_{2}$, the most typical photocatalyst, has received the most extensive research. However, its wide bandgap only responds to UV light [11-13]. Hence, more photocatalysts with suitable and efficient bandgaps have been developed and used, such as Bi-based catalysts [14], $\mathrm{C}_{3} \mathrm{~N}_{4}$ [15], and $\mathrm{ZnO}$ [16]. At present, there have been many active reports 
on photocatalysis in organic wastewater treatment [17], water splitting for hydrogen and oxygen production [18], and nitrogen fixation [19]. Since photocatalysis does not require additional energy input besides light, the active species that are produced have good redox capabilities and do not produce additional pollution [20]. It is highly feasible to use it for redox in water treatment.

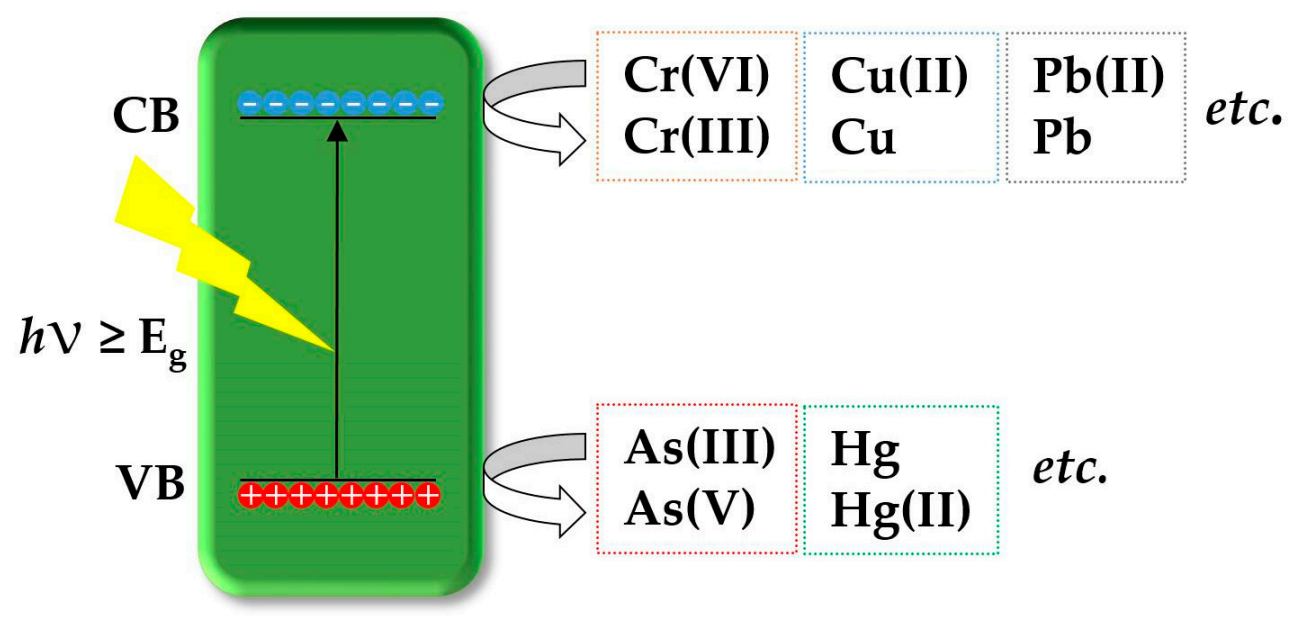

\section{Photocatalyst}

Figure 1. Schematic diagram of photocatalytic treatment of heavy metals.

Table 1. Health effects of exposure to several heavy metal elements (Adapted from [21]).

\begin{tabular}{|c|c|c|c|}
\hline Heavy Metals & Use/Exposure & Health Effects & $\begin{array}{l}\text { Maximum } \\
\text { Contamination Level } \\
\left(\mathrm{WHO}^{*}\right)[22]\end{array}$ \\
\hline Chromium (Cr) & $\begin{array}{l}\text { Electroplating/Lather tanning/ } \\
\text { paint industry }\end{array}$ & Respiratory cancers & $50 \mathrm{ppb}$ \\
\hline Zinc $(\mathrm{Zn})$ & Mining/manufacturing & Metal fume fever/restlessness & / \\
\hline Cadmium $(\mathrm{Cd})$ & $\begin{array}{l}\text { Electroplating/pigment/plastic/ } \\
\text { polymerization industry }\end{array}$ & Bone damage/nephrotoxic effects & $3 \mathrm{ppb}$ \\
\hline Mercury (Hg) & $\begin{array}{l}\text { Pesticides/chlorine-alkali/paint/ } \\
\text { petrochemical industry }\end{array}$ & $\begin{array}{c}\text { Dyslexia/neurobehavioral } \\
\text { disorders/intellectual retardation/attention } \\
\text { deficit hyperactivity disorder }\end{array}$ & $1 \mathrm{ppb}$ \\
\hline Nickel (Ni) & Electroplating/mining/paint industry & $\begin{array}{l}\text { Chronic bronchitis/cancers of the lungs and } \\
\text { nasal sinus/decreased lung function }\end{array}$ & / \\
\hline Platinum (Pt) & Mining/catalytic converter & $\begin{array}{c}\text { Platinosis/allergic reactions/respiratory } \\
\text { hypersensitive reaction }\end{array}$ & / \\
\hline Arsenic (As) & Mining/wood preservative/biocides & $\begin{array}{l}\text { Skin cancers/liver tumours/acute } \\
\text { poisoning/gastrointestinal issues }\end{array}$ & $10 \mathrm{ppb}$ \\
\hline
\end{tabular}

( ${ }^{*}$ WHO—World Health Organization; ppb-parts per billion).

\section{Traditional Heavy Metal Treatment}

Typical industrial methods employed in wastewater treatment, such as adsorption, chemical precipitation, ion exchange, ozonation, biological methods, and electrochemical methods activated by carbon, can hardly reduce the metal concentration in water to within the regulatory standards effectively [23]. This is because there is a considerable number of heavy metals in water that are complexed with organic chelating agents that come from textile, nuclear, and electroplating sources. With copper as an example, the adsorption efficiency is $49.3 \%$ of the original under competitive chelation with EDTA [24]. Figure 2 presents a schematic diagram of the most typical electrochemical water treatment tank. Its complete removal requires the assistance of other technologies, though it can effectively oxidize and reduce heavy metals. Moreover, the requirements of electrochemical treatment on equipment parameters and the huge power consumption also cannot be underestimated. 


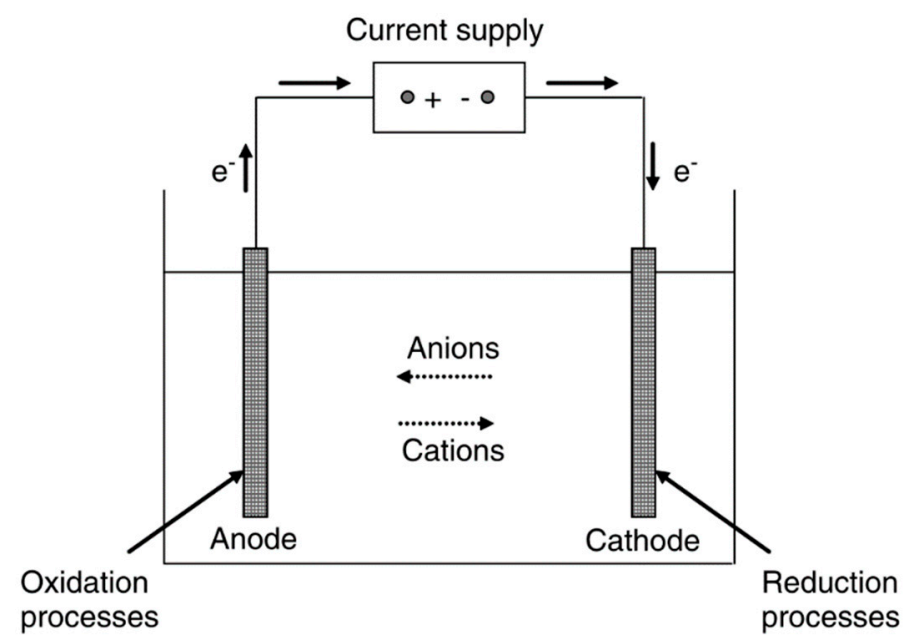

Figure 2. Schematic diagram of electrochemical reactor (Adapted from [25]).

Metals can be precipitated by the addition of coagulants such as alum, lime, alum salts, and other organic polymers. This method is used by almost three-quarters of plating companies. Among them, the most common precipitation methods include sulphide, sodium hydroxide, and carbonate methods. However, the major disadvantage of this process is the large amount of toxic sludge that is produces [26].

Additionally, there are some more processes that can be used to complete heavy metal treatment. Nonetheless, they have their defects, which are summarized in Table 2.

Table 2. Traditional heavy metal processing techniques and their drawbacks.

\begin{tabular}{|c|c|c|}
\hline Techniques & Drawbacks & Ref. \\
\hline Direct adsorption & Inefficient in the presence of ligand & [24] \\
\hline Chemical precipitation & Inefficient in the presence of ligand and potential pollution & [26] \\
\hline Ozonation & Difficulties in separation and potential contamination & [23] \\
\hline Ultrafiltration & Sludge generation & [27] \\
\hline Ion-exchange & High cost and partial removal of some ions & {$[28]$} \\
\hline Reverse osmosis & High cost & [29] \\
\hline Electrowinning & $\begin{array}{l}\text { Many equipment restrictions, large investment and continuous } \\
\text { power input demand }\end{array}$ & [30] \\
\hline Carbon adsorption & High cost and low adsorption rates of water-soluble components & [31] \\
\hline Phytoremediation & Time-consuming and difficult to regenerate plants & [32] \\
\hline
\end{tabular}

The good redox ability of photocatalytic technology and the performance and adaptability in the treatment of organic pollutants in water [33] enable it to be used for the recovery of heavy metals. Its main advantage is that it does not require energy input other than light energy, which is different from many traditional processes and is beneficial to its continuous operation [34]. In photocatalytic redox, no polluting intermediates are produced. This is another important advantage. This environmentally friendly feature is consistent with the purpose of water treatment [35]. Finally, photoreactions can be adopted to deposit heavy metals that are easily reduced on the surface of the catalyst in the form of solids to achieve the effect of direct separation from the solution [36]. These characteristics of photocatalysis are not available in many traditional heavy metal processing techniques.

\section{Photocatalytic Heavy Metal Treatment}

As mentioned above, the unique advantages of photocatalysis equip it with great potential in the treatment of heavy metals $[11,14,34,37]$. Therefore, it has also attracted the attention of many researchers [38-49]. Some reported examples of the photocatalytic treatment of heavy metals are provided in Table 3. The specific situations of different heavy metals in photocatalytic treatments are detailed as follows. 
Table 3. Overview of applications of photocatalytic heavy metal treatment.

\begin{tabular}{|c|c|c|c|c|c|c|}
\hline Photocatalyst & Heavy Metal & Redox Products & Light Type & Efficiency & $\begin{array}{l}\text { Irradiation } \\
\text { Time }\end{array}$ & Ref. \\
\hline Porous BNNSs $/ \mathrm{TiO}_{2}$ & $\mathrm{Cr}(\mathrm{VI})$ & $\mathrm{Cr}(\mathrm{III})$ & $\begin{array}{l}\text { Simulated solar light } \\
\text { and visible light }\end{array}$ & $99 \%$ and $99 \%$ & $\begin{array}{l}70 \text { min and } \\
80 \text { min }\end{array}$ & [50] \\
\hline $\mathrm{TiO}_{2}$ hollow sphere & $\mathrm{Cr}(\mathrm{VI})$ & $\mathrm{Cr}$ (III) & UV light & $0.0867 \mathrm{~min}^{-1}$ & $80 \mathrm{~min}$ & [51] \\
\hline 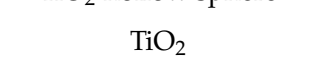 & $\mathrm{Cr}(\mathrm{VI})$ & $\mathrm{Cr}(\mathrm{III})$ & Visible light & $\begin{array}{l}100 \% \text { (formic acid } \\
\text { as electron donor) }\end{array}$ & $80 \mathrm{~min}$ & [52] \\
\hline $\begin{array}{l}\mathrm{TiO}_{2} \text { nanotube } \\
\text { arrays } / \mathrm{Ag}-\mathrm{AgBr}\end{array}$ & $\mathrm{Cr}(\mathrm{VI})$ & $\mathrm{Cr}(\mathrm{III})$ & Solar light & $58.63 \%$ & $180 \mathrm{~min}$ & [53] \\
\hline $\mathrm{CdS} / \mathrm{TiO}_{2}$ & $\mathrm{Cr}(\mathrm{VI})$ & $\mathrm{Cr}(\mathrm{III})$ & Visible light & $2.14 \times 10^{-2} \mathrm{~min}^{-1}$ & $180 \min$ & [54] \\
\hline $\mathrm{ZnTiO}_{3} / \mathrm{Zn}_{2} \mathrm{Ti}_{3} \mathrm{O}_{8} / \mathrm{ZnO}$ & $\mathrm{Cr}(\mathrm{VI})$ & $\mathrm{Cr}(\mathrm{III})$ & Full spectrum light & $47 \%$ & $150 \mathrm{~min}$ & [55] \\
\hline ZnO-graphene & $\mathrm{Cr}(\mathrm{VI})$ & $\mathrm{Cr}(\mathrm{III})$ & UV light & $98 \%$ & $240 \mathrm{~min}$ & [56] \\
\hline Ag/ZnO@CF & $\mathrm{Cr}(\mathrm{VI})$ & $\mathrm{Cr}$ (III) & Full spectrum light & $71.82 \%$ & $210 \min$ & [16] \\
\hline $\mathrm{PW}_{12} / \mathrm{CN} @ \mathrm{Bi}_{2} \mathrm{WO}_{6}$ & $\mathrm{Cr}(\mathrm{VI})$ & $\mathrm{Cr}$ (III) & Visible light & $98.7 \%$ & $90 \mathrm{~min}$ & [57] \\
\hline $\begin{array}{c}\mathrm{g}-\mathrm{C}_{3} \mathrm{~N}_{4} / \text { diatomite } \\
\text { composites } / \mathrm{Ag} / \mathrm{AgCl}\end{array}$ & $\mathrm{Cr}(\mathrm{VI})$ & $\mathrm{Cr}(\mathrm{III})$ & Visible light & $7.4 \times 10^{-2} \mathrm{~min}^{-1}$ & $45 \mathrm{~min}$ & [58] \\
\hline $\mathrm{Nb}_{2} \mathrm{O}_{5}$ & $\mathrm{Cr}(\mathrm{VI})$ & $\mathrm{Cr}(\mathrm{III})$ & Full spectrum light & $90 \%$ & $120 \mathrm{~min}$ & [59] \\
\hline $\mathrm{ZrO}_{2}$ & $\mathrm{Cr}(\mathrm{VI})$ & $\mathrm{Cr}(\mathrm{III}) / \mathrm{Cr}$ & UV light & About $100 \%$ & $90 \mathrm{~min}$ & [60] \\
\hline $\begin{array}{l}\text { Iron(III) cross-linking } \\
\text { alginate hydrogel beads } \\
\text { Cellulose }\end{array}$ & $\mathrm{Cr}(\mathrm{VI})$ and $\mathrm{As}(\mathrm{III})$ & $\mathrm{Cr}(\mathrm{III})$ and $\mathrm{As}(\mathrm{V})$ & Full spectrum light & $90 \%$ and $100 \%$ & $150 \mathrm{~min}$ & [61] \\
\hline $\begin{array}{l}\text { acetate/chitosan/single } \\
\text { walled carbon nan- } \\
\text { otubes/ferrite/titanium } \\
\text { dioxide }\end{array}$ & $\mathrm{Cr}(\mathrm{VI})$ and $\mathrm{As}(\mathrm{V})$ & $\mathrm{Cr}(\mathrm{III})$ and $\mathrm{As}$ & UV light & $\begin{array}{c}0.0925 \text { and } 0.0896 \\
\min ^{-1}\end{array}$ & $60 \mathrm{~min}$ & [62] \\
\hline $\mathrm{BiOI}$ & As(III) & $\mathrm{As}(\mathrm{V})$ & Natural light & $1 \mathrm{mg} / \mathrm{L}$ to $10 \mu \mathrm{g} / \mathrm{L}$ & $3 \mathrm{~h}$ & [63] \\
\hline $\mathrm{TiO}_{2}$ & As(III) & $\mathrm{As}(\mathrm{V})$ & UV light & About $100 \%$ & $30 \mathrm{~min}$ & {$[64]$} \\
\hline $\mathrm{TiO}_{2}-\mathrm{ZrO}_{2}$ & $\mathrm{Cu}(\mathrm{II})$ and $\mathrm{Cr}(\mathrm{VI})$ & $\mathrm{Cu}$ and $\mathrm{Cr}(\mathrm{III}) / \mathrm{Cr}$ & UV light & 96.29 and $99.17 \%$ & $630 \mathrm{~min}$ & [65] \\
\hline $\mathrm{TiO}_{2} / \mathrm{Alg} / \mathrm{FeNPs}$ & $\begin{array}{c}\mathrm{Cr}(\mathrm{III}), \mathrm{Cu}(\mathrm{II}) \text { and } \\
\mathrm{Pb}(\mathrm{II})\end{array}$ & $\mathrm{Cr}, \mathrm{Cu}$ and $\mathrm{Pb}$ & UV light & $\begin{array}{c}98.6 \%, 98.4 \% \text { and } \\
99.5 \%\end{array}$ & $120 \mathrm{~min}$ & [66] \\
\hline$\alpha-\mathrm{Fe}_{2} \mathrm{O}_{3} / g-\mathrm{C}_{3} \mathrm{~N}_{4}$ & $\mathrm{Hg}(\mathrm{II})$ & $\mathrm{Hg}$ & Visible light & $90 \%$ & $60 \mathrm{~min}$ & [67] \\
\hline $\mathrm{BiOI} / \mathrm{BiOCl}$ & $\mathrm{Hg}$ & $\mathrm{HgO} / \mathrm{Hg}$ (II) & Visible light & $72.4 \%$ & $50 \mathrm{~min}$ & [68] \\
\hline $\mathrm{CeO}_{2} / \mathrm{BiOIO}_{3}$ & $\mathrm{Hg}$ & $\mathrm{HgO}$ & Visible light & $86.53 \%$ & $30 \mathrm{~min}$ & [69] \\
\hline $\mathrm{BiOIO}_{3} / \mathrm{MoS}_{2} / \mathrm{C} 500$ & $\mathrm{Hg}$ & $\mathrm{HgO}$ & UV light & $78.32 \%$ & $70 \mathrm{~min}$ & [70] \\
\hline $\mathrm{Ag} / \mathrm{TiO}_{2}$ & $\begin{array}{c}\mathrm{Cd}(\mathrm{II}), \mathrm{Ni}(\mathrm{II}), \\
\mathrm{Zn}(\mathrm{II}), \mathrm{Mn}(\mathrm{II}) \text { and } \\
\mathrm{Cu}(\mathrm{II})\end{array}$ & $\begin{array}{l}\mathrm{Cd}, \mathrm{Ni}, \mathrm{Zn}, \mathrm{Mn} \\
\quad \text { and } \mathrm{Cu}\end{array}$ & UV light & $\begin{array}{l}100,96,65.13,58.22 \\
\quad \text { and } 56.20 \%\end{array}$ & $120 \mathrm{~min}$ & [71] \\
\hline $\mathrm{NiFe}_{2} \mathrm{O}_{4}-\mathrm{Pd}$ & $\mathrm{Pb}(\mathrm{II})$ and $\mathrm{Cd}(\mathrm{II})$ & $\mathrm{Pb}$ and $\mathrm{Cd}$ & Full spectrum light & $\begin{array}{l}1.4 \times 10^{-1} \text { and } 0.86 \\
\quad \times 10^{-1} \mathrm{~min}^{-1}\end{array}$ & $60 \mathrm{~min}$ & [72] \\
\hline Chitosan/Ag & $\begin{array}{c}\mathrm{Cu}(\mathrm{II}), \mathrm{Pb}(\mathrm{II}) \text { and } \\
\mathrm{Cd}(\mathrm{II})\end{array}$ & $\mathrm{Cu}, \mathrm{Pb}$ and $\mathrm{Cd}$ & Natural sunlight & $\begin{array}{c}1.10 \times 10^{-4}, 1.4 \times \\
10^{-4} \text { and } 1.5 \times 10^{-4} \\
\mathrm{~mol} \mathrm{dm}^{-3} \mathrm{~s}^{-1}\end{array}$ & $240 \mathrm{~min}$ & [73] \\
\hline $\mathrm{SnO}_{2}$ nanoparticles & $\mathrm{Co}(\mathrm{II})$ & Co & UV light & $94 \%$ & $60 \mathrm{~min}$ & [74] \\
\hline
\end{tabular}

\subsection{Chromium ( $\mathrm{Cr}$ )}

Chromium is the most studied and most typical metal in heavy metal removal studies. It is a metal with numerous industrial and technological applications in fields such as electroplating, the textile industry, wood preservation, and metallurgy. The production of wastewater containing chromium ions is inevitable with the use of chromium. $\mathrm{Cr}(\mathrm{VI})$ ions have been discovered to be more toxic than $\mathrm{Cr}(\mathrm{III})$ ions. Compared to $\mathrm{Cr}(\mathrm{III})$, which is more thermodynamically stable, long-term exposure to $\mathrm{Cr}(\mathrm{VI})$ can damage the nasal septum, cause lung cancer, and result in skin ulcers [75]. Among heavy metal ions, the treatment of $\mathrm{Cr}(\mathrm{VI})$ ions is the most studied. Some works have been published on the photocatalytic reduction of $\mathrm{Cr}(\mathrm{VI})$ using $\mathrm{TiO}_{2-}, \mathrm{ZnO}-, \mathrm{CdS}-$, and $\mathrm{ZnS}-$ based catalysts [16,50-62,65].

In 2005, Tuprakay et al. successfully photo-reduced $\mathrm{Cr}(\mathrm{VI})$ by using immobilized $\mathrm{TiO}_{2}$ under a UV light intensity of $171 \mathrm{~W} / \mathrm{m}^{2}$ in $32 \mathrm{~h}$. The $\mathrm{Cr}(\mathrm{VI})$ adsorption followed firstorder kinetics, while the reduction exhibited zero-order kinetics [76]. Five years later, Idris et al. observed that the initial concentration of the $\mathrm{Cr}(\mathrm{VI})$ present before photoreduction plays a crucial role in determining its removal efficiency. At an equilibrium state, the removal efficiency of $\mathrm{Cr}(\mathrm{VI})$ at initial concentrations of 25, 50, 75, 100, 125, and $150 \mathrm{mg} / \mathrm{L}$ was revealed to be $100 \%, 100 \%, 100 \%, 100 \%, 70 \%$, and $70 \%$ in $100 \mathrm{~min}$, respectively. A further investigation indicates that the percentage adsorption of $\mathrm{Cr}(\mathrm{VI})$ decreased with 
the increasing initial $\mathrm{Cr}(\mathrm{VI})$ concentration. Moreover, this experiment was conducted in sunlight with the use of magnetically separable photocatalyst beads, allowing it to be achieved in less time [77]. The photocatalytic reduction of $\mathrm{Cr}(\mathrm{VI})$ is feasible under visible light. Dye-photosensitized $\mathrm{TiO}_{2}$ samples successfully reduced $\mathrm{Cr}(\mathrm{VI})$ under visible light.

Di Iorio et al. reported a high efficiency in $\mathrm{Cr}(\mathrm{VI})$ reduction by using alizarin red chelated to $\mathrm{TiO}_{2}$. This was slightly dependent on the $\mathrm{Cr}(\mathrm{VI})$ concentration and was independent of the photon flux and the irradiation wavelength [78]. At a $\mathrm{pH}$ of 2, a rapid reduction of $\mathrm{Cr}(\mathrm{VI})$ was observed when visible light was irradiated on $\mathrm{TiO}_{2}$ coated with hydroxyl aluminium tricarboxymonoamide phthalocyanine (AITCPc) in the presence of 4-chlorophenol (4-CP) as a sacrificial donor assisting in preventing the photobleaching of AITCPc [79]. Figure 3a illustrates that the phthalocyanine (Pc) on the surface of $\mathrm{TiO}_{2}$ will excite electrons and holes when photo-sensitized. This is different from the photocatalysis principle of a single material. Moreover, they will migrate to $\mathrm{CB}$ and $\mathrm{VB}$ for their respective oxidation and reduction reactions. Figure $3 \mathrm{~b}$ presents the energy band change after the coupling of $\mathrm{TiO}_{2}$ and AITCPc. It can also reflect the migration process of excited electrons on AITCPc to the $\mathrm{CB}$ of $\mathrm{TiO}_{2}$. In this way, the coupling effect between different materials can weaken the light utilization efficiency of the entire photocatalytic system, improve the separation efficiency of photogenerated carriers, and enhance the overall reduction ability and efficiency of the entire photocatalytic system to $\mathrm{Cr}(\mathrm{VI})$. On the excitation of the dye, an electron was injected into the conduction band to promote $\mathrm{Cr}(\mathrm{VI})$ reduction $[79,80]$. In these photoreduction studies, most of the $\mathrm{Cr}(\mathrm{VI})$ ions are reduced to $\mathrm{Cr}$ (III) ions, while only a small part is reduced to $\mathrm{Cr}$ atoms [60,65].

$$
\begin{gathered}
\mathrm{Cr}(\mathrm{VI})+\mathrm{e}^{-} \rightarrow \mathrm{Cr}(\mathrm{V}) \\
\mathrm{Cr}(\mathrm{V})+\mathrm{e}^{-} \rightarrow \mathrm{Cr}(\mathrm{IV}) \\
\mathrm{Cr}(\mathrm{IV})+\mathrm{e}^{-} \rightarrow \mathrm{Cr}(\mathrm{III}) \\
\mathrm{Cr}_{2} \mathrm{O}_{7}{ }^{2-}+6 \mathrm{e}^{-}+14 \mathrm{H}^{+} \rightarrow 2 \mathrm{Cr}^{3+}+7 \mathrm{H}_{2} \mathrm{O}\left(\mathrm{E}^{0}=+1.33 \mathrm{~V}\right)
\end{gathered}
$$

The photocatalytic treatment of $\mathrm{Cr}(\mathrm{VI})$ is a complete photoreduction process, which is largely affected by the following three factors:

1. A low $\mathrm{pH}$ that favors the net reaction in Equation (3); however, neutral or alkaline conditions favor the precipitation and immobilization of $\mathrm{Cr}$ (III) as the oxides or hydroxides, contributing to enhancing separation even further [81-83].

2. The addition of organic compounds can accelerate the reduction of $\mathrm{Cr}(\mathrm{VI})$ by acting as hole or $\cdot \mathrm{OH}$ scavengers [84].

3. $\mathrm{Cr}(\mathrm{VI})$ reduction is independent of molecular oxygen, especially at a low $\mathrm{pH}$ [65].

(a)

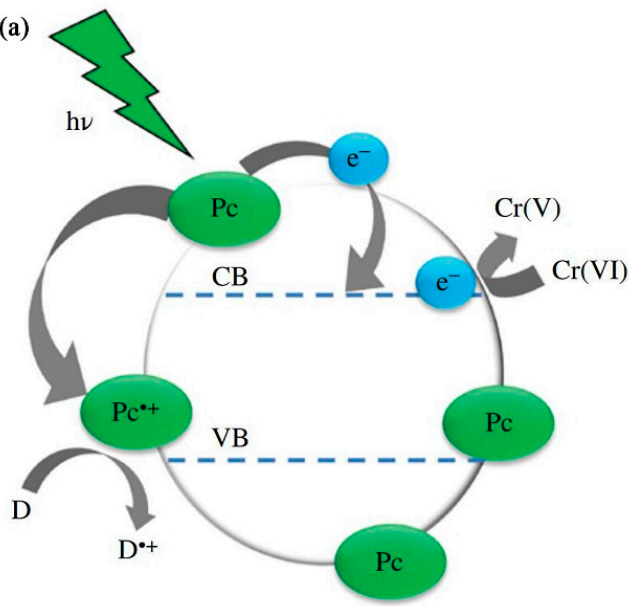

(b)

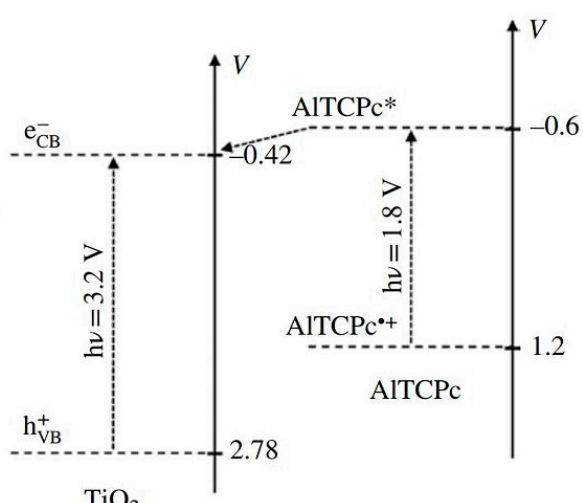

$\mathrm{pH} 2$

Figure 3. (a) Schematic diagram of heterogeneous photocatalytic reduction of $\mathrm{Cr}(\mathrm{VI})$ under visible light and (b) energy band of $\mathrm{TiO}_{2}$ modified with AITCPc (Adapted from [79]). 
In addition to $\mathrm{Cr}(\mathrm{VI})$, there are also studies on the removal of $\mathrm{Cr}(\mathrm{III})$ ions. Devagi et al. treated wastewater containing three heavy metal ions: $\mathrm{Cr}(\mathrm{III}), \mathrm{Cu}(\mathrm{II})$, and $\mathrm{Pb}(\mathrm{II})$, at the same time. They revealed that the adsorption in their system can significantly contribute to the removal of heavy metal ions instead of photoreduction [66].

\subsection{Arsenic (As)}

As another common heavy metal element, arsenic is highly toxic. This has been demonstrated through the long-term drinking of arsenic-containing water causing various cancers [64]. In addition to the risk of carcinogenesis and acute poisoning, some investigations suggest that chronic arsenic poisoning can impact mental health and the neurobehavior of children, causing long-term and irreversible social harm [85,86]. In an aqueous solution, arsenic mainly exists in the forms of As(III) and As(V). Compared to $\mathrm{As}(\mathrm{III}), \mathrm{As}(\mathrm{V})$ ions are less toxic and are more easily adsorbed and removed [87]. When $\mathrm{pH}<9$, it mainly exists in the non-ionic form of $\mathrm{H}_{3} \mathrm{AsO}_{3}$, which is difficult to remove by simple coagulation precipitation or adsorption because of the neutrality and difficult ionization of $\mathrm{H}_{3} \mathrm{AsO}_{3}[88,89]$. Recently, Zhang et al. effectively achieved the removal of $\mathrm{Cr}(\mathrm{VI}) / \mathrm{As}$ (III) by applying iron(III) cross-linking alginate hydrogel beads (Fe-SA) as photocatalyst under simulated sunlight. The Fe-SA system used $\mathrm{Fe}(\mathrm{II})$ and $\mathrm{CO}_{2}$ as intermediates while reducing $\mathrm{Cr}(\mathrm{VI})$ and oxidizing $\mathrm{As}(\mathrm{III})$ by the photoinduced ligand to metal charge transfer under UV light and adsorbing them (Figure 4). This efficient synergistic system enables the two heavy metals to reach more than $80 \%$ in a wide $\mathrm{pH}$ range (3-7). In this study, $\mathrm{Cr}(\mathrm{VI})$ was reduced to $\mathrm{Cr}(\mathrm{III})$ ions, and As(III) was oxidized to As(V) ions. Then, they were adsorbed or settled, allowing them to be removed from the water [61].

Photocatalysis offers a low-cost alternative in treatments to remove arsenic from wastewater. Meichtry et al. impregnated the walls of PET plastic bottles with $\mathrm{TiO}_{2}$, which is the most typical and most commonly used photocatalyst. As(III) solutions of $1000 \mu \mathrm{g} / \mathrm{L}$ at a $\mathrm{pH}$ of 7.8 were placed in the bottles and were irradiated by UV light for $6 \mathrm{~h}$; finally, a removal efficiency of $80-86 \%$ was recorded for arsenic; this process could be repeated up to three times without any loss of efficiency [90]. The removal efficiency of $94 \%$ was recorded in the photooxidation of As from well water samples (taken from Las Hermanas, Santiago del Estero Province, Argentina). This was performed under solar irradiation with the addition of $\mathrm{FeCl}_{3}$ at the end of the experiment. It was discovered to be within the limits of the World Health Organization (WHO).

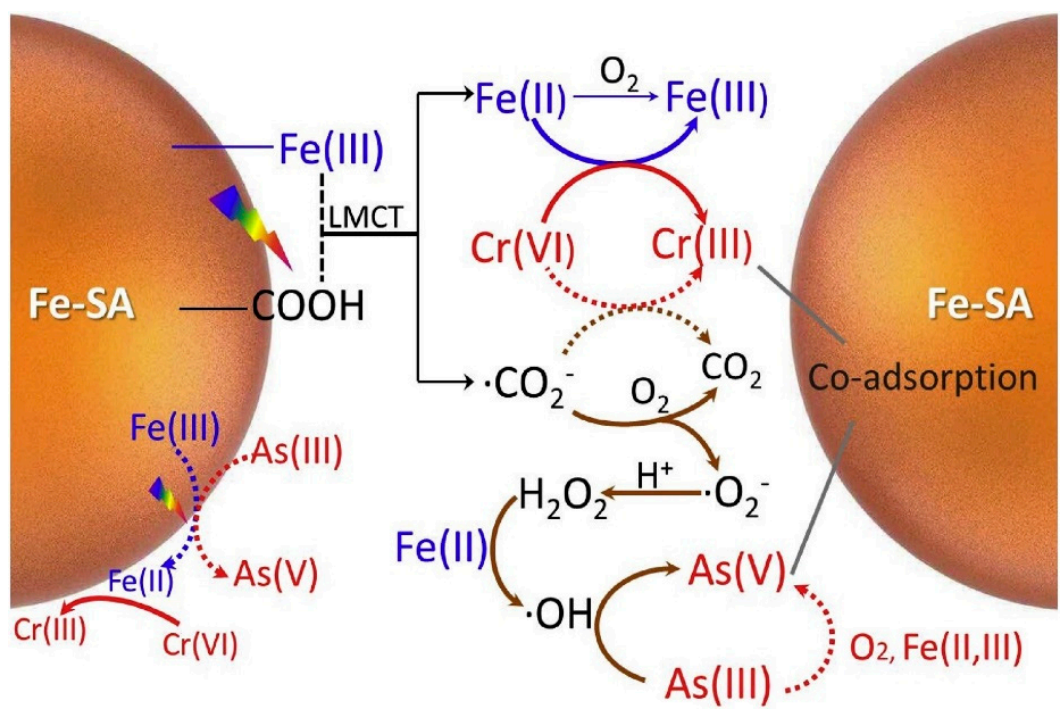

Figure 4. Schematic diagram of photocatalytic simultaneous conversion of $\mathrm{Cr}(\mathrm{VI})$ and $\mathrm{As}(\mathrm{III})$. (LMCT-ligand to metal charge transfer) (Adapted from [61]). 
Simultaneously, there have also been explorations on the reduction and removal of $\mathrm{As}(\mathrm{V})$ [62]. Research demonstrates that $\mathrm{As}(\mathrm{V})$ can be reduced in the dark by accumulated electrons through the UV irradiation of $\mathrm{TiO}_{2}$ nanoparticles in alcohol. The accumulation of electrons and their participation in the reduction of $\mathrm{As}(\mathrm{V})$ was detected as Ti(III) by UV-vis spectrophotometry [91,92].

\section{3. $\operatorname{Mercury}(\mathrm{Hg})$}

The ingestion of mercury by organisms can cause permanent enzyme inactivation, leaving a devastating effect on metabolic functions [93]. Unlike other heavy metal forms of pollution, mercury is liquid at room temperature. The flow properties of mercury liquid and steam can significantly boost the permeability and scope of pollution. In cases where ions have similar toxicity to other heavy metals, the elemental form of mercury also has strong toxicity and diffusivity. Thus, $\mathrm{Hg}(0)$ and $\mathrm{Hg}(\mathrm{II})$ have different photocatalytic treatment methods.

Chen et al. revealed that $\mathrm{Ag}(\mathrm{I}), \mathrm{Pb}(\mathrm{II}), \mathrm{Hg}(\mathrm{II}), \mathrm{Cr}(\mathrm{VI})$, and $\mathrm{Fe}(\mathrm{III})$ can be reduced by photocatalysis after 65 min of irradiation using $\mathrm{TiO}_{2}$ as the photocatalyst, with a removal efficiency of $99.7 \%, 27.2 \%, 70 \%, 79.1 \%$, and $100 \%$, respectively [94]. Kadi et al. employed $\alpha-\mathrm{Fe}_{2} \mathrm{O}_{3} / \mathrm{g}-\mathrm{C}_{3} \mathrm{~N}_{4}$ to reduce $\mathrm{Hg}(\mathrm{II})$ in water under visible light. Within $60 \mathrm{~min}, 100 \mathrm{mg} / \mathrm{L}$ of $\mathrm{Hg}$ (II) was completely converted [67]. The photocatalyst adopted in their study exhibited good activity in the photoreduction process and could be used to reduce other heavy metal ions. Regarding mercury ions, simple reduction is not enough for the removal of heavy metal elements. After the mercury ions are reduced to elemental mercury, adsorption may be an indispensable part of this process.

Due to its low water solubility and high volatility, $\mathrm{Hg}(0)$ is generally considered more difficult to remove than $\mathrm{Hg}(\mathrm{II})$. Several reports have verified that Bi-based photocatalysts show good activity in $\mathrm{Hg}(0)$ removal $[69,70]$. The $\mathrm{BiOI} / \mathrm{BiOCl}$ microflowers prepared by Sun et al. can effectively photocatalyze oxidation and trap $\mathrm{Hg}$ in the gas phase [68]. Different from ordinary heterostructures, the unique multi-level charge transport path of this microflower-like $\mathrm{BiOCl} / \mathrm{BiOI}$ alternate arrangement structure equips it with better charge transport and photo-generated carrier separation capabilities. The mechanism diagram is illustrated in Figure 5. The experimental results suggest that the $\mathrm{Hg}$ removal rate of this microflower $\mathrm{BiOCl} / \mathrm{BiOI}$ is as high as $72.2 \%$, which is more than four times the efficiency of pure $\mathrm{BiOCl}$ and $\mathrm{BiOI}$.

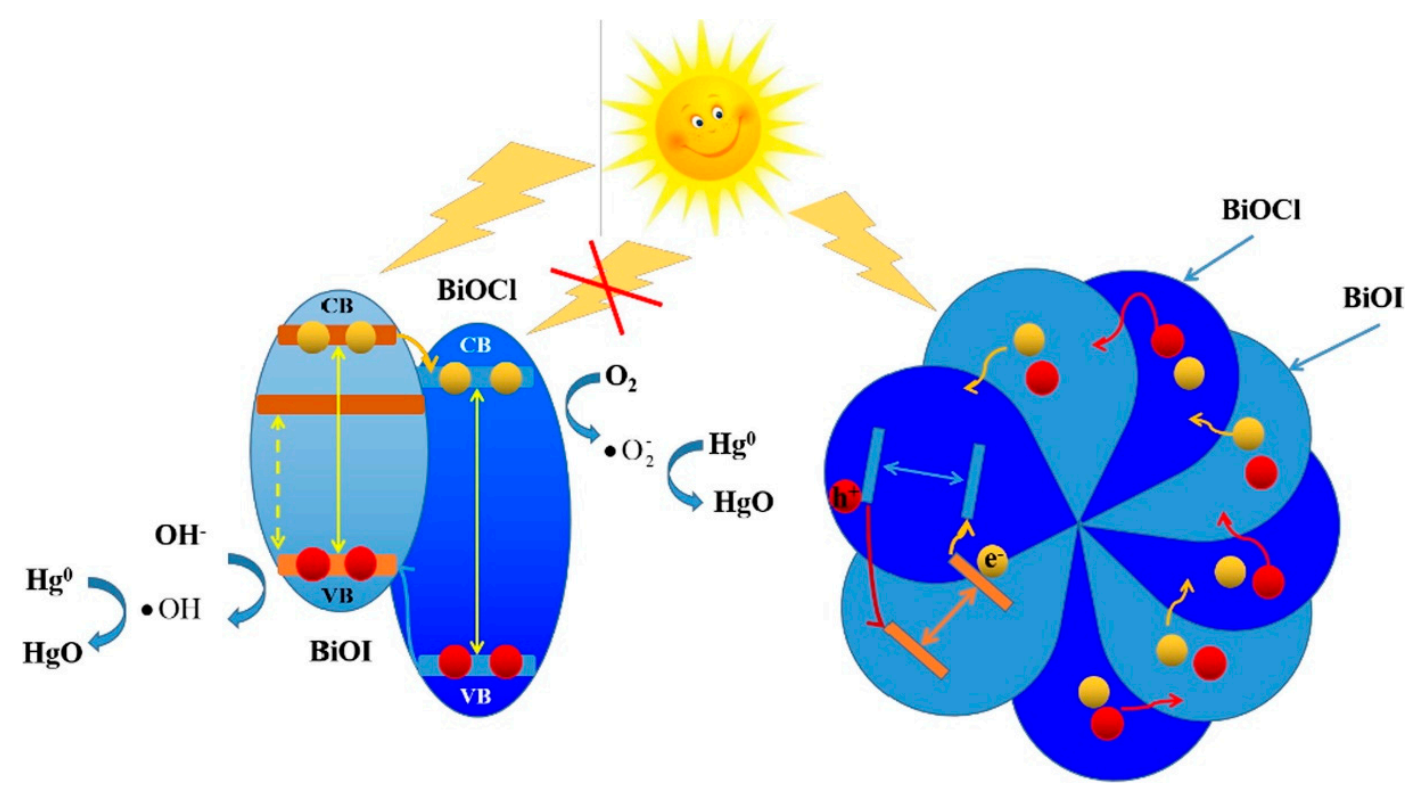

Figure 5. The mechanism of photocatalytic removal of gas-phase $\mathrm{Hg}(0)$ under visible light (Adapted from [68]). 
To sum up, it is a more feasible and reasonable treatment to oxidize the elemental state of $\mathrm{Hg}$ to $\mathrm{Hg}(\mathrm{II})$ and to then remove it in the form of $\mathrm{HgO}$.

\subsection{Other Heavy Metals}

Moreover, there are many kinds of heavy metal elements that are potentially harmful to the environment. These are not as typical as $\mathrm{Cr}(\mathrm{VI})$, nor are they as special as $\mathrm{Hg}$. Considering that simple photoreduction combined with adsorption can effectively treat these heavy metals, they are classified into the same category. Cadmium $(\mathrm{Cd})$, lead $(\mathrm{Pb})$, copper $(\mathrm{Cu})$, zinc $(\mathrm{Zn})$, manganese $(\mathrm{Mn})$, nickel $(\mathrm{Ni})$, and cobalt $(\mathrm{Co})$ are also common heavy metals. They will threaten environmental safety and human health when existing in the form of ions in the solution.

Wahyuni et al. explained that $\mathrm{Cr}(\mathrm{VI}), \mathrm{Cu}(\mathrm{II})$, and $\mathrm{Cd}(\mathrm{II})$ can be reduced photocatalytically, while $\mathrm{Pb}$ (II) ions preferably oxidize than reduce because of their negative reduction potential value.

$$
\begin{array}{ll}
\mathrm{Cu}^{2+}+2 \mathrm{e}^{-} \rightarrow \mathrm{Cu}^{0} & \left(\mathrm{E}^{0}=+0.34 \mathrm{~V}\right) \\
\mathrm{Cd}^{2+}+2 \mathrm{e}^{-} \rightarrow \mathrm{Cd}^{0} & \left(\mathrm{E}^{0}=-0.403 \mathrm{~V}\right) \\
\mathrm{Pb}^{2+} \rightarrow \mathrm{Pb}^{4+}+2 \mathrm{e}^{-} & \left(\mathrm{E}^{0}=-0.67 \mathrm{~V}\right)
\end{array}
$$

In the removal of heavy metals, the influence of $\mathrm{pH}$ is a critical factor influencing the sedimentation of ions. According to reports, the optimum $\mathrm{pH}$ is 5 in such a system. At this $\mathrm{pH}$, the removal efficiency of $15 \%, 40 \%, 45 \%$, and $75 \%$ was achieved for $\mathrm{Cd}(\mathrm{II}), \mathrm{Pb}$ (II), $\mathrm{Cu}(\mathrm{II})$, and $\mathrm{Cr}(\mathrm{VI})$, respectively. At a more alkaline $\mathrm{pH}(\mathrm{pH} 13), \mathrm{Cr}(\mathrm{VI})$ is hardly removed effectively, while the removal rate of $\mathrm{Cd}(\mathrm{II}), \mathrm{Pb}$ (II), and $\mathrm{Cu}(\mathrm{II})$ is close to $100 \%$.

\section{Discussion and Outlooks}

Photocatalytic removal of heavy metals is an essential part of photocatalytic water treatment. At present, the removal of various heavy metal elements using photocatalytic technology has been extensively studied. In this study, the typical works of this research topic are summarized. Although this process has presented advantages, there are still obstacles in its future applications. Possible solutions to existing problems and recommendations for future work are suggested as follows:

1. Low photocatalytic efficiency: At present, the efficiency of the photocatalytic reaction remains low. This is reflected not only in the removal of heavy metals but also in other photocatalytic processes. This situation is expected to be improved as more new materials presenting higher catalytic activity and higher stability efficiency or modification methods (such as doping and morphology control) that can improve the photocatalytic activity and stability of existing materials are proposed.

2. Low light utilization efficiency: Although natural solar energy resources are extremely abundant, the current light energy that can be utilized by photocatalysis is still very low. From one perspective, this is caused by the poor response of the photocatalyst to visible light. From another perspective, it is related to the current photocatalytic system. The former can be improved through the improvement of materials while the latter may require breakthroughs in reactor design.

3. Continuous operation method: It is difficult to remove heavy metals through simple oxidation or reduction. It is a common photocatalytic treatment method to convert difficult-to-treat heavy metal atoms or ions into a form that is easier to adsorb or settle and before removal. Its practical application would lie in the organic combination of the catalytic process and the adsorption/sedimentation process to ensure that the entire process has better overall continuity.

4. No standard platform: Although there is a WHO standard for the removal of heavy metals, this standard has not been widely adopted, especially in photocatalysis re- 
search. Moreover, the existing research on the use of light sources and other aspects of the divergence is sufficient. To date, no standard platform can use a unified standard to evaluate the photoactivity of different photocatalysts in different laboratories. The establishment of this standard is necessary and urgent.

5. Technology coupling: With the current efficiency of photocatalysis, it is significantly difficult to complete the task of water treatment on its own. Generally, the combination of different technologies is effective. It may be a good choice to organically combine the photocatalytic system with the existing water treatment technology.

Current research has demonstrated that photocatalytic technology can play a role in the removal of heavy metals. However, there are still many problems in this process, such as low efficiency, difficult separation, and difficult catalyst regeneration. Therefore, this advanced technology requires further development.

Author Contributions: Conceptualization, Literature review, Writing-Original draft preparation (X.G.); Supervision, Writing - Original draft preparation, review and editing, manuscript submission and correspondence (X.M.). All authors have read and agreed to the published version of the manuscript.

Funding: This research was funded by Taishan Scholars Foundation of Shandong province (Grant No.: tsqn201909058) and the Fundamental Research Funds for the Central Universities (Grant No.: 202013037).

Institutional Review Board Statement: Not applicable.

Informed Consent Statement: Not applicable.

Data Availability Statement: Not applicable.

Conflicts of Interest: There are no conflicts of interest to declare.

\section{References}

1. Litter, M.I. Mechanisms of removal of heavy metals and arsenic from water by $\mathrm{TiO}_{2}$-heterogeneous photocatalysis. Pure Appl. Chem. 2015, 87, 557-567. [CrossRef]

2. Fu, F.; Wang, Q. Removal of heavy metal ions from wastewaters: A review. J. Environ. Manag. 2011, 92, 407-418. [CrossRef]

3. Gao, X.; Yao, Y.; Meng, X. Recent development on BN-based photocatalysis: A review. Mater. Sci. Semicond. Process. 2020, 120, 105256. [CrossRef]

4. Yao, Y.; Gao, X.; Li, Z.; Meng, X. Photocatalytic Reforming for Hydrogen Evolution: A Review. Catalysts 2020, 10, 335. [CrossRef]

5. Yao, Y.; Gao, X.; Meng, X. Recent advances on electrocatalytic and photocatalytic seawater splitting for hydrogen evolution. Int. J. Hydrogen Energy 2021, 46, 9087-9100. [CrossRef]

6. Yao, Y.; Ren, G.; Li, Z.; Bai, H.; Hu, X.; Meng, X. Nitrogen Vacancy-Induced Deposition of Pd Nanoparticles onto g-C $\mathrm{C}_{3} \mathrm{~N}_{4}$ with Greatly Improved Photocatalytic Activity in $\mathrm{H}_{2}$ Evolution. Sol. RRL 2021, 5, 2100145. [CrossRef]

7. Argurio, P.; Fontananova, E.; Molinari, R.; Drioli, E. Photocatalytic membranes in photocatalytic membrane reactors. Processes 2018, 6, 162. [CrossRef]

8. Ullah, H.; Viglašová, E.; Galamboš, M. Visible Light-Driven Photocatalytic Rhodamine B Degradation Using CdS Nanorods. Processes 2021, 9, 263. [CrossRef]

9. Ulyankina, A.; Mitchenko, S.; Smirnova, N. Selective photocatalytic oxidation of 5-HMF in water over electrochemically synthesized $\mathrm{TiO}_{2}$ nanoparticles. Processes 2020, 8, 647. [CrossRef]

10. Wang, C.; Sun, X.; Shan, H.; Zhang, H.; Xi, B. Degradation of Landfill Leachate Using UV-TiO 2 Photocatalysis Combination with Aged Waste Reactors. Processes 2021, 9, 946. [CrossRef]

11. Li, Z.; Meng, X.; Zhang, Z. Recent development on $\mathrm{MoS}_{2}$-based photocatalysis: A review. J. Photochem. Photobiol. C Photochem. Rev. 2018, 35, 39-55. [CrossRef]

12. Mukherjee, D.; Barghi, S.; Ray, A.K. Preparation and characterization of the $\mathrm{TiO}_{2}$ immobilized polymeric photocatalyst for degradation of aspirin under UV and solar light. Processes 2014, 2, 12-23. [CrossRef]

13. Mukherjee, D.; Ray, A.K.; Barghi, S. Mechanism of acetyl salicylic acid (aspirin) degradation under solar light in presence of a $\mathrm{TiO}_{2}$-polymeric film photocatalyst. Processes 2016, 4, 13. [CrossRef]

14. Meng, X.; Zhang, Z. Bismuth-based photocatalytic semiconductors: Introduction, challenges and possible approaches. J. Mol. Catal. A Chem. 2016, 423, 533-549. [CrossRef]

15. Safaei, J.; Ullah, H.; Mohamed, N.A.; Mohamad Noh, M.F.; Soh, M.F.; Tahir, A.A.; Ahmad Ludin, N.; Ibrahim, M.A.; Wan Isahak, W.N.R.; Mat Teridi, M.A. Enhanced photoelectrochemical performance of Z-scheme g- $\mathrm{C}_{3} \mathrm{~N}_{4} / \mathrm{BiVO}_{4}$ photocatalyst. Appl. Catal. B Environ. 2018, 234, 296-310. [CrossRef] 
16. Liang, H.; Li, T.; Zhang, J.; Zhou, D.; Hu, C.; An, X.; Liu, R.; Liu, H. 3-D hierarchical Ag/ZnO@CF for synergistically removing phenol and $\mathrm{Cr}(\mathrm{VI})$ : Heterogeneous vs. homogeneous photocatalysis. J. Colloid Interface Sci. 2020, 558, 85-94. [CrossRef] [PubMed]

17. Li, Z.; Zhang, Z.; Wang, L.; Meng, X. Bismuth chromate $\left(\mathrm{Bi}_{2} \mathrm{CrO}_{6}\right)$ : A promising semiconductor in photocatalysis. J. Catal. 2020, 382, 40-48. [CrossRef]

18. Zhu, C.; Liu, C.; Fu, Y.; Gao, J.; Huang, H.; Liu, Y.; Kang, Z. Construction of CDs/CdS photocatalysts for stable and efficient hydrogen production in water and seawater. Appl. Catal. B Environ. 2019, 242, 178-185. [CrossRef]

19. Di, J.; Xia, J.; Chisholm, M.F.; Zhong, J.; Chen, C.; Cao, X.; Dong, F.; Chi, Z.; Chen, H.; Weng, Y.X.; et al. Defect-Tailoring Mediated Electron-Hole Separation in Single-Unit-Cell $\mathrm{Bi}_{3} \mathrm{O}_{4} \mathrm{Br}$ Nanosheets for Boosting Photocatalytic Hydrogen Evolution and Nitrogen Fixation. Adv. Mater. 2019, 31, e1807576. [CrossRef]

20. Li, Z.; Meng, X.; Zhang, Z. Fabrication of surface hydroxyl modified g-C3N4with enhanced photocatalytic oxidation activity. Catal. Sci. Technol. 2019, 9, 3979-3993. [CrossRef]

21. Chowdhury, P.; Elkamel, A.; Ray, A.K. Photocatalytic Processes for the Removal of Toxic Metal Ions. In Heavy Metals in Water: Presence, Removal and Safety; Royal Society of Chemistry: London, UK, 2014; pp. 25-43.

22. WHO Regional Office for Europe. Health Risks of Heavy Metals from Long-Range Transboundary Air Pollution; WHO Regional Office for Europe: Copenhagen, Denmark, 2007. Available online: https://www.euro.who.int/en/publications/abstracts/health-risksof-heavy-metals-from-long-range-transboundary-air-pollution-2007 (accessed on 19 September 2021).

23. Subramani, A.; Jacangelo, J.G. Emerging desalination technologies for water treatment: A critical review. Water Res. 2015, 75, 164-187. [CrossRef]

24. Song, L.; Zhao, R.; Yun, D.; Lu, P.; He, J.; Wang, X. Influence of Co (II), Ni (II), tartrate, and ethylenediaminetetraacetic acid on Cu (II) adsorption onto a polyvinylidene fluoride-based chelating membrane. Toxicol. Environ. Chem. 2014, 96, 362-378. [CrossRef]

25. Anglada, Á.; Urtiaga, A.; Ortiz, I. Contributions of electrochemical oxidation to waste-water treatment: Fundamentals and review of applications. J. Chem. Technol. Biotechnol. 2009, 84, 1747-1755. [CrossRef]

26. Ramachandra, T.V.; Ahalya, N.; Kanamadi, R.D. Biosorption: Techniques and mechanisms. CES Tech. Rep. 2005, $110,1-91$.

27. Trivunac, K.; Stevanovic, S. Removal of heavy metal ions from water by complexation-assisted ultrafiltration. Chemosphere 2006, 64, 486-491. [CrossRef] [PubMed]

28. Joshi, N.C. Heavy metals, conventional methods for heavy metal removal, biosorption and the development of low cost adsorbent. Eur. J. Pharm. Med. Res. 2017, 4, 388-393.

29. Bakalár, T.; Búgel, M.; Gajdošová, L. Heavy metal removal using reverse osmosis. Acta Montanistica Slovaca $2009,14,250$.

30. U.S. Congress, Office of Technology Assessment. Copper: Technology and Competiveness; U.S. Government Printing Office: Washington, DC, USA, 1998.

31. Fiyadh, S.S.; AlSaadi, M.A.; Jaafar, W.Z.; AlOmar, M.K.; Fayaed, S.S.; Mohd, N.S.; Hin, L.S.; El-Shafie, A. Review on heavy metal adsorption processes by carbon nanotubes. J. Clean. Prod. 2019, 230, 783-793. [CrossRef]

32. Pulford, I.D.; Watson, C. Phytoremediation of heavy metal-contaminated land by trees-A review. Environ. Int. 2003, 29, 529-540. [CrossRef]

33. Hasanpour, M.; Hatami, M. Photocatalytic performance of aerogels for organic dyes removal from wastewaters: Review study. J. Mol. Liq. 2020, 309, 113094. [CrossRef]

34. Meng, X.; Zhang, Z.; Li, X. Synergetic photoelectrocatalytic reactors for environmental remediation: A review. J. Photochem. Photobiol. C Photochem. Rev. 2015, 24, 83-101. [CrossRef]

35. Kubota, Y.; Watanabe, K.; Tsuda, O.; Taniguchi, T. Deep Ultraviolet Light-Emitting Hexagonal Boron Nitride Synthesized at Atmospheric Pressure. Science 2007, 317, 932. [CrossRef] [PubMed]

36. Xie, W.; Zhang, M.; Liu, D.; Lei, W.; Sun, L.; Wang, X. Photocatalytic $\mathrm{TiO}_{2}$ / porous BNNSs composites for simultaneous LR2B and $\mathrm{Cr}(\mathrm{VI})$ removal in wool dyeing bath. J. Photochem. Photobiol. A Chem. 2017, 333, 165-173. [CrossRef]

37. Meng, X.; Yun, N.; Zhang, Z. Recent advances in computational photocatalysis: A review. Can. J. Chem. Eng. 2019, 97, 1982-1998. [CrossRef]

38. Lazar, M.; Varghese, S.; Nair, S. Photocatalytic Water Treatment by Titanium Dioxide: Recent Updates. Catalysts $2012,2,572-601$. [CrossRef]

39. Mozia, S.; Morawski, A.W.; Toyoda, M.; Tsumura, T. Effect of process parameters on photodegradation of Acid Yellow 36 in a hybrid photocatalysis-membrane distillation system. Chem. Eng. J. 2009, 150, 152-159. [CrossRef]

40. Chen, C.; Ma, W.; Zhao, J. Semiconductor-mediated photodegradation of pollutants under visible-light irradiation. Chem. Soc. Rev. 2010, 39, 4206-4219. [CrossRef]

41. Qu, Y.; Duan, X. Progress, challenge and perspective of heterogeneous photocatalysts. Chem. Soc. Rev. 2013, 42, 2568-2580. [CrossRef]

42. Ni, Y.; Wang, W.; Huang, W.; Lu, C.; Xu, Z. Graphene strongly wrapped TiO2 for high-reactive photocatalyst: A new sight for significant application of graphene. J. Colloid Interface Sci. 2014, 428, 162-169. [CrossRef]

43. Chen, G.; Sun, M.; Wei, Q.; Zhang, Y.; Zhu, B.; Du, B. Ag3PO4/graphene-oxide composite with remarkably enhanced visiblelight-driven photocatalytic activity toward dyes in water. J. Hazard. Mater. 2013, 244, 86-93. [CrossRef]

44. Su, J.; Zhang, Y.; Xu, S.; Wang, S.; Ding, H.; Pan, S.; Wang, G.; Li, G.; Zhao, H. Highly efficient and recyclable triple-shelled Ag@ $\mathrm{Fe}_{3} \mathrm{O}_{4} @ \mathrm{SiO}_{2} @ \mathrm{TiO}_{2}$ photocatalysts for degradation of organic pollutants and reduction of hexavalent chromium ions. Nanoscale 2014, 6, 5181-5192. [CrossRef] [PubMed] 
45. Dong, S.; Feng, J.; Fan, M.; Pi, Y.; Hu, L.; Han, X.; Liu, M.; Sun, J.; Sun, J. Recent developments in heterogeneous photocatalytic water treatment using visible light-responsive photocatalysts: A review. RSC Adv. 2015, 5, 14610-14630. [CrossRef]

46. Casbeer, E.; Sharma, V.K.; Li, X.-Z. Synthesis and photocatalytic activity of ferrites under visible light: A review. Sep. Purif. Technol. 2012, 87, 1-14. [CrossRef]

47. Bahnemann, D. Photocatalytic water treatment: Solar energy applications. Sol. Energy 2004, 77, 445-459. [CrossRef]

48. Chong, M.N.; Jin, B.; Chow, C.W.; Saint, C. Recent developments in photocatalytic water treatment technology: A review. Water Res. 2010, 44, 2997-3027. [CrossRef]

49. Li, F.-F.; Yang, D.-F.; Xia, M.-S.; Wang, Y.; Jiang, Y.-S. Visible-light photocatalytic activity of Sn (2+)-doped TiO (2) and its loading effect on mesoporous montmorillonite. Wuji Cailiao Xuebao J. Inorg. Mater. 2011, 26, 917-922. [CrossRef]

50. Liu, D.; Zhang, M.W.; Xie, W.J.; Sun, L.; Chen, Y.; Lei, W.W. Efficient photocatalytic reduction of aqueous Cr(VI) over porous BNNSs $/ \mathrm{TiO}_{2}$ nanocomposites under visible light irradiation. Catal. Sci. Technol. 2016, 6, 8309-8313. [CrossRef]

51. Yang, Y.; Wang, G.; Deng, Q.; Wang, H.; Zhang, Y.; Ng, D.H.L.; Zhao, H. Enhanced photocatalytic activity of hierarchical structure $\mathrm{TiO}_{2}$ hollow spheres with reactive (001) facets for the removal of toxic heavy metal Cr(VI). RSC Adv. 2014, 4, 34577-34583. [CrossRef]

52. Zhang, X.; Song, L.; Zeng, X.; Li, M. Effects of electron donors on the $\mathrm{TiO}_{2}$ photocatalytic reduction of heavy metal ions under visible light. Energy Procedia 2012, 17, 422-428. [CrossRef]

53. Cao, D.; Wang, Q.; Liu, Z.; Zhang, H.; Wang, Y.; Jin, R.; Gao, S. Enhanced the photoelectrocatalytic performance of TiO 2 nanotube arrays by the synergistic sensitization of Ag-AgBr nanospheres. Spectrochim. Acta A Mol. Biomol. Spectrosc. 2020, $227,117674$. [CrossRef]

54. Deng, Y.; Xiao, Y.; Zhou, Y.; Zeng, T.; Xing, M.; Zhang, J. A structural engineering-inspired CdS based composite for photocatalytic remediation of organic pollutant and hexavalent chromium. Catal. Today 2019, 335, 101-109. [CrossRef]

55. Chen, F.; Yu, C.; Wei, L.; Fan, Q.; Ma, F.; Zeng, J.; Yi, J.; Yang, K.; Ji, H. Fabrication and characterization of $\mathrm{ZnTiO}_{3} / \mathrm{Zn}_{2} \mathrm{Ti}_{3} \mathrm{O}_{8} / \mathrm{ZnO}$ ternary photocatalyst for synergetic removal of aqueous organic pollutants and Cr(VI) ions. Sci. Total Environ. 2020, 706, 136026. [CrossRef] [PubMed]

56. Liu, X.; Pan, L.; Lv, T.; Lu, T.; Zhu, G.; Sun, Z.; Sun, C. Microwave-assisted synthesis of ZnO-graphene composite for photocatalytic reduction of $\mathrm{Cr}(\mathrm{VI})$. Catal. Sci. Technol. 2011, 1, 1189-1193. [CrossRef]

57. Yang, R.; Zhong, S.; Zhang, L.; Liu, B. $\mathrm{PW}_{12} / \mathrm{CN} @ \mathrm{Bi}_{2} \mathrm{WO}_{6}$ composite photocatalyst prepared based on organic-inorganic hybrid system for removing pollutants in water. Sep. Purif. Technol. 2020, 235, 116270. [CrossRef]

58. He, H.; Li, J.; Yu, C.; Luo, Z. Surface decoration of microdisk-like g- $\mathrm{C}_{3} \mathrm{~N}_{4}$ /diatomite with $\mathrm{Ag} / \mathrm{AgCl}$ nanoparticles for application in $\mathrm{Cr}(\mathrm{VI})$ reduction. Sustain. Mater. Technol. 2019, 22, e00127. [CrossRef]

59. Josue, T.G.; Almeida, L.N.B.; Lopes, M.F.; Santos, O.A.A.; Lenzi, G.G. Cr(VI) reduction by photocatalyic process: $\mathrm{Nb}_{2} \mathrm{O}_{5}$ an alternative catalyst. J. Environ. Manag. 2020, 268, 110711. [CrossRef]

60. Jiang, W.; Liu, Q.; Tao, Y.; Mu, K.; Wang, Z.; Zhu, Y.; Yue, H.; Liang, B. An environment-friendly strategy for one-step turning $\mathrm{Cr}(\mathrm{VI})$ contaminant into a Cr-Loaded catalyst for $\mathrm{CO}_{2}$ utilization. Adv. Sustain. Syst. 2018, 2, 1700165. [CrossRef]

61. Zhang, W.; Liu, F.; Sun, Y.; Zhang, J.; Hao, Z. Simultaneous redox conversion and sequestration of chromate (VI) and arsenite (III) by iron (III)-alginate based photocatalysis. Appl. Catal. B Environ. 2019, 259, 118046. [CrossRef]

62. ZabihiSahebi, A.; Koushkbaghi, S.; Pishnamazi, M.; Askari, A.; Khosravi, R.; Irani, M. Synthesis of cellulose acetate/chitosan/ SWCNT $/ \mathrm{Fe}_{3} \mathrm{O}_{4} / \mathrm{TiO}_{2}$ composite nanofibers for the removal of $\mathrm{Cr}(\mathrm{VI})$, $\mathrm{As}(\mathrm{V})$, methylene blue and congo red from aqueous solutions. Int. J. Biol. Macromol. 2019, 140, 1296-1304. [CrossRef]

63. Hu, J.; Weng, S.; Zheng, Z.; Pei, Z.; Huang, M.; Liu, P. Solvents mediated-synthesis of BiOI photocatalysts with tunable morphologies and their visible-light driven photocatalytic performances in removing of arsenic from water. J. Hazard. Mater. 2014, 264, 293-302. [CrossRef]

64. Dutta, P.K.; Pehkonen, S.O.; Sharma, V.K.; Ray, A.K. Photocatalytic oxidation of arsenic (III): Evidence of hydroxyl radicals. Environ. Sci. Technol. 2005, 39, 1827-1834. [CrossRef]

65. Yan, R.; Luo, D.; Fu, C.; Wang, Y.; Zhang, H.; Wu, P.; Jiang, W. Harmless treatment and selective recovery of acidic Cu (II)-Cr(VI) hybrid wastewater via coupled photo-reduction and ion exchange. Sep. Purif. Technol. 2020, 234, 116130. [CrossRef]

66. Kanakaraju, D.; Rusydah bt Mohamad Shahdad, N.; Lim, Y.-C.; Pace, A. Concurrent removal of Cr(III), Cu (II), and Pb (II) ions from water by multifunctional $\mathrm{TiO}_{2} / \mathrm{Alg} / \mathrm{FeNPs}$ beads. Sustain. Chem. Pharm. 2019, 14, 100176. [CrossRef]

67. Kadi, M.W.; Mohamed, R.M.; Ismail, A.A.; Bahnemann, D.W. Performance of mesoporous $\alpha-\mathrm{Fe}_{2} \mathrm{O}_{3} / g-\mathrm{C}_{3} \mathrm{~N}_{4}$ heterojunction for photoreduction of $\mathrm{Hg}$ (II) under visible light illumination. Ceram. Int. 2020, 46, 23098-23106. [CrossRef]

68. Sun, X.; Lu, J.; Wu, J.; Guan, D.; Liu, Q.; Yan, N. Enhancing photocatalytic activity on gas-phase heavy metal oxidation with self-assembled BiOI/BiOCl microflowers. J. Colloid Interface Sci. 2019, 546, 32-42. [CrossRef] [PubMed]

69. Xiao, Y.; Tan, S.; Wang, D.; Wu, J.; Jia, T.; Liu, Q.; Qi, Y.; Qi, X.; He, P.; Zhou, M. $\mathrm{CeO}_{2} / \mathrm{BiOIO}_{3}$ heterojunction with oxygen vacancies and $\mathrm{Ce}^{4+} / \mathrm{Ce}^{3+}$ redox centers synergistically enhanced photocatalytic removal heavy metal. Appl. Surf. Sci. 2020, 530, 147116. [CrossRef]

70. Jia, T.; Xu, K.; Wu, J.; Liu, Q.; Lin, Y.; Gu, M.; Tian, F.; Pan, W.; Wu, J.; Xiao, Y. Constructing $2 \mathrm{D} \mathrm{BiOIO}_{3} / \mathrm{MoS}_{2} \mathrm{Z}$-scheme heterojunction wrapped by $\mathrm{C} 500$ as charge carriers transfer channel: Enhanced photocatalytic activity on gas-phase heavy metal oxidation. J. Colloid Interface Sci. 2020, 562, 429-443. [CrossRef] [PubMed] 
71. Elleuch, L.; Messaoud, M.; Djebali, K.; Attafi, M.; Cherni, Y.; Kasmi, M.; Elaoud, A.; Trabelsi, I.; Chatti, A. A new insight into highly contaminated landfill leachate treatment using Kefir grains pre-treatment combined with Ag-doped TiO ${ }_{2}$ photocatalytic process. J. Hazard. Mater. 2020, 382, 121119. [CrossRef] [PubMed]

72. Thomas, B.; Alexander, L.K. Removal of $\mathrm{Pb}^{2+}$ and $\mathrm{Cd}^{2+}$ toxic heavy metal ions driven by Fermi level modification in $\mathrm{NiFe}_{2} \mathrm{O}_{4}-\mathrm{Pd}^{2}$ nano hybrids. J. Solid State Chem. 2020, 288, 121417. [CrossRef]

73. Al-Sherbini, A.A.; Ghannam, H.E.A.; El-Ghanam, G.M.A.; El-Ella, A.A.; Youssef, A.M. Utilization of chitosan/Ag bionanocomposites as eco-friendly photocatalytic reactor for Bactericidal effect and heavy metals removal. Heliyon 2019, 5, e01980. [CrossRef]

74. Ebrahimian, J.; Mohsennia, M.; Khayatkashani, M. Photocatalytic-degradation of organic dye and removal of heavy metal ions using synthesized $\mathrm{SnO}_{2}$ nanoparticles by vitex agnus-castus fruit via a green route. Mater. Lett. 2020, 263, 127255. [CrossRef]

75. McCarron, P.; Harvey, I.; Brogan, R.; Peters, T.J. Self reported health of people in an area contaminated by chromium waste: Interview study. BMJ 2000, 320, 11-15. [CrossRef]

76. Tuprakay, S.; Liengcharernsit, W. Lifetime and regeneration of immobilized titania for photocatalytic removal of aqueous hexavalent chromium. J. Hazard. Mater. 2005, 124, 53-58. [CrossRef]

77. Idris, A.; Hassan, N.; Rashid, R.; Ngomsik, A.-F. Kinetic and regeneration studies of photocatalytic magnetic separable beads for chromium (VI) reduction under sunlight. J. Hazard. Mater. 2011, 186, 629-635. [CrossRef]

78. Iorio, Y.D.; Román, E.S.; Litter, M.I.; Grela, M.A. Photoinduced reactivity of strongly coupled $\mathrm{TiO}_{2}$ ligands under visible irradiation: An examination of an alizarin red@ $\mathrm{TiO}_{2}$ nanoparticulate system. J. Phys. Chem. C 2008, 112, 16532-16538. [CrossRef]

79. Litter, M.I.; Quici, N. New advances of heterogeneous photocatalysis for treatment of toxic metals and arsenic. In Nanomaterials for Environmental Protection; Wiley: Hoboken, NJ, USA, 2014; pp. 143-167.

80. Meichtry, J.M.; Rivera, V.; Iorio, Y.D.; Rodríguez, H.B.; Román, E.S.; Grela, M.A.; Litter, M.I. Photoreduction of Cr(VI) using hydroxoaluminiumtricarboxymonoamide phthalocyanine adsorbed on $\mathrm{TiO}_{2}$. Photochem. Photobiol. Sci. 2009, 8, 604-612. [CrossRef] [PubMed]

81. Sahel, K.; Elsellami, L.; Mirali, I.; Dappozze, F.; Bouhent, M.; Guillard, C. Hydrogen peroxide and photocatalysis. Appl. Catal. B Environ. 2016, 188, 106-112. [CrossRef]

82. Nosaka, Y.; Nosaka, A.Y. Generation and Detection of Reactive Oxygen Species in Photocatalysis. Chem. Rev. 2017, 117, 11302-11336. [CrossRef] [PubMed]

83. Lousada, C.M.; Johansson, A.J.; Brinck, T.; Jonsson, M. Mechanism of $\mathrm{H}_{2} \mathrm{O}_{2}$ Decomposition on Transition Metal Oxide Surfaces. J. Phys. Chem. C 2012, 116, 9533-9543. [CrossRef]

84. Zhang, J.; Nosaka, Y. Photocatalytic oxidation mechanism of methanol and the other reactants in irradiated $\mathrm{TiO}_{2}$ aqueous suspension investigated by OH radical detection. Appl. Catal. B Environ. 2015, 166-167, 32-36. [CrossRef]

85. Smedley, P.L.; Kinniburgh, D.G. A review of the source, behaviour and distribution of arsenic in natural waters. Appl. Geochem. 2002, 17, 517-568. [CrossRef]

86. Rehman, K.; Fatima, F.; Waheed, I.; Akash, M.S.H. Prevalence of exposure of heavy metals and their impact on health consequences. J. Cell. Biochem. 2018, 119, 157-184. [CrossRef]

87. Guan, X.; Du, J.; Meng, X.; Sun, Y.; Sun, B.; Hu, Q. Application of titanium dioxide in arsenic removal from water: A review. J. Hazard. Mater. 2012, 215-216, 1-16. [CrossRef]

88. Mamindy-Pajany, Y.; Hurel, C.; Marmier, N.; Roméo, M. Arsenic (V) adsorption from aqueous solution onto goethite, hematite, magnetite and zero-valent iron: Effects of $\mathrm{pH}$, concentration and reversibility. Desalination 2011, 281, 93-99. [CrossRef]

89. Mohan, D.; Pittman, C.U. Arsenic removal from water/wastewater using adsorbents-A critical review. J. Hazard. Mater. 2007, 142, 1-53. [CrossRef] [PubMed]

90. Meichtry, J.M.; Lin, H.J.; Luciana, D.; Levy, I.K.; Gautier, E.A.; Blesa, M.A.; Litter, M.I. Low-cost TiO 2 photocatalytic technology for water potabilization in plastic bottles for isolated regions photocatalyst fixation. J. Sol. Energy Eng. 2007, 129, 119-126. [CrossRef]

91. Levy, I.K.; Brusa, M.A.; Aguirre, M.E.; Custo, G.; San Román, E.; Litter, M.I.; Grela, M.A. Exploiting electron storage in TiO 2 nanoparticles for dark reduction of As(V) by accumulated electrons. Phys. Chem. Chem. Phys. 2013, 15, 10335-10338. [CrossRef] [PubMed]

92. Levy, I.K.; Quici, N.; Custo, G.; Litter, M.I.; Brusa, M.; Aguirre, M.E.; Grela, M.A.; San Román, E. Dark reduction of As(V) by accumulated electrons stored in alcoholic $\mathrm{TiO}_{2}$ nanoparticles. In Proceedings of the 5th International Congress on Arsenic in the Environment, Buenos Aires, Argentina, 11-16 May 2014; pp. 802-804.

93. Ynalvez, R.; Gutierrez, J.; Gonzalez-Cantu, H. Mini-review: Toxicity of mercury as a consequence of enzyme alteration. Biometals 2016, 29, 781-788. [CrossRef]

94. Chen, D.; Ray, K.A. Removal of toxic metal ions from wastewater by semiconductor photocatalysis. Chem. Eng. Sci. 2001, 56, 1561-1570. [CrossRef] 